\title{
Landscape analysis of the family planning situation in Pakistan-District profile: Faisalabad
}

Population Council

Follow this and additional works at: https://knowledgecommons.popcouncil.org/departments_sbsr-rh

Part of the Demography, Population, and Ecology Commons, Family, Life Course, and Society Commons, and the International Public Health Commons How does access to this work benefit you? Let us know!

\section{Recommended Citation}

"Landscape analysis of the family planning situation in Pakistan-District profile: Faisalabad." Islamabad: Population Council, 2016. 


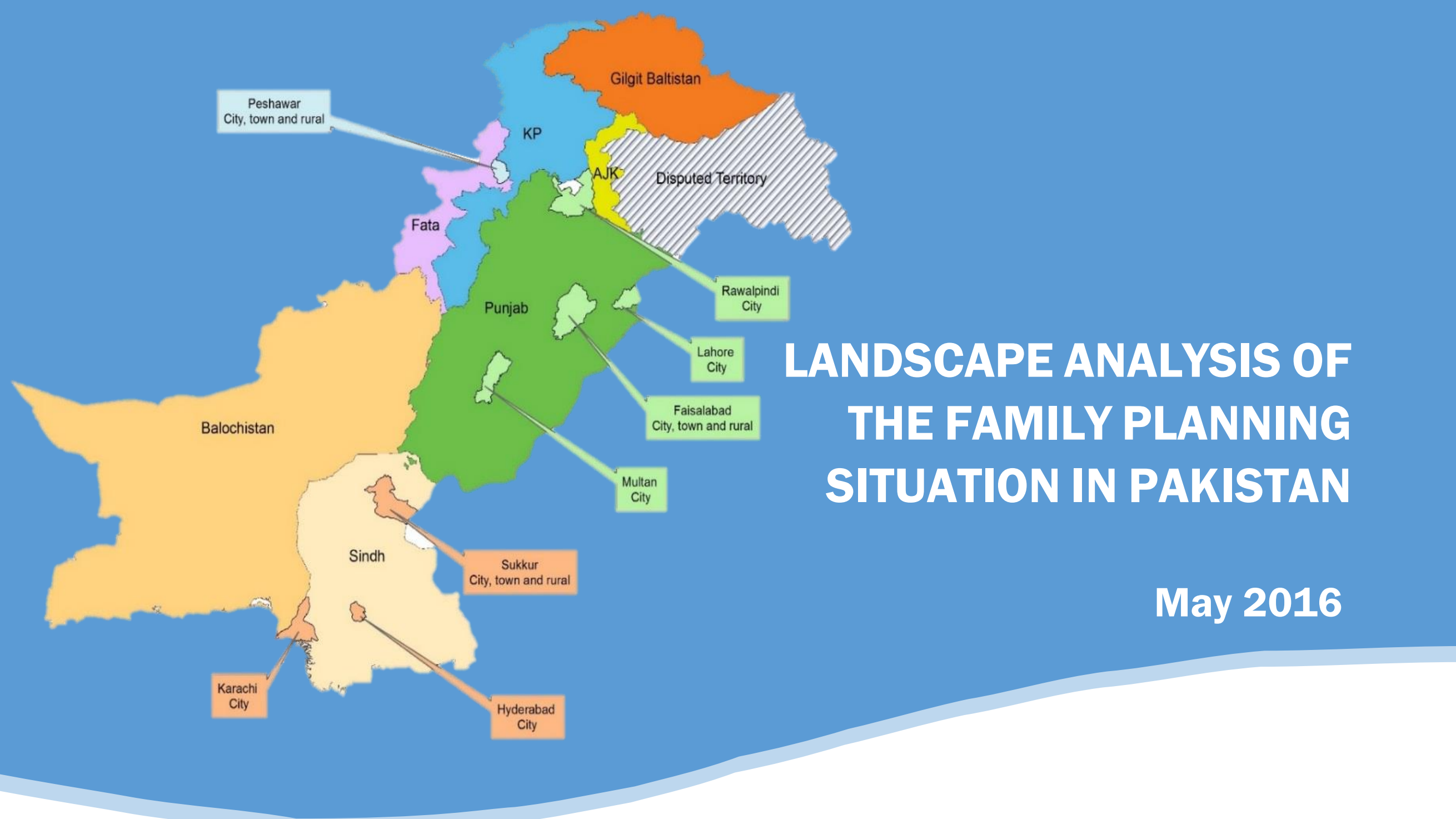

\section{DISTRICT PROFILE: FAISALABAD}

BILL MELINDA

GATES foundation
POPULATION COUNCIL 


\section{Background}

Faisalabad District is situated in central Punjab Province. It has an estimated population of 7.4 million ${ }^{1}$. The district consists of eight administrative strata, or towns. Table 1 presents key demographic facts about the district. Less than half $(42 \%)$ of the population is urban. ${ }^{2}$ Of the estimated 1.9 million women of reproductive age (MWRA) in the district, 1.15 million lives in urban areas. At 3.4, Faisalabad's total fertility rate (TFR) is below Punjab's average of 3.5.3

Table 1: Demographics of Faisalabad

\begin{tabular}{|c|c|c|c|}
\hline Demographics & Urban & Rural & Overall \\
\hline Total population & $3,142,000$ & $4,216,000$ & $7,358,000$ \\
\hline Women 15-49 & 875,000 & $1,038,000$ & $1,913,000$ \\
\hline MWRA & 489,000 & 663,000 & $1,152,000$ \\
\hline $\begin{array}{l}\text { Literacy rate ( } 10 \\
\text { years and above) * }\end{array}$ & $77 \%$ & $61 \%$ & $69 \%$ \\
\hline $\mathrm{IMR}^{* *}$ & - & - & 69 \\
\hline TFR $* *$ & - & - & 3.4 \\
\hline \multicolumn{4}{|c|}{$\begin{array}{l}\text { Source: Punjab Development Statistics 2015, * Pakistan Social and Living } \\
\text { Standards Measurement Survey (PSLMS) 2014-15, **Multiple Indicator } \\
\text { Cluster Survey Punjab (MICS) } 2014\end{array}$} \\
\hline
\end{tabular}

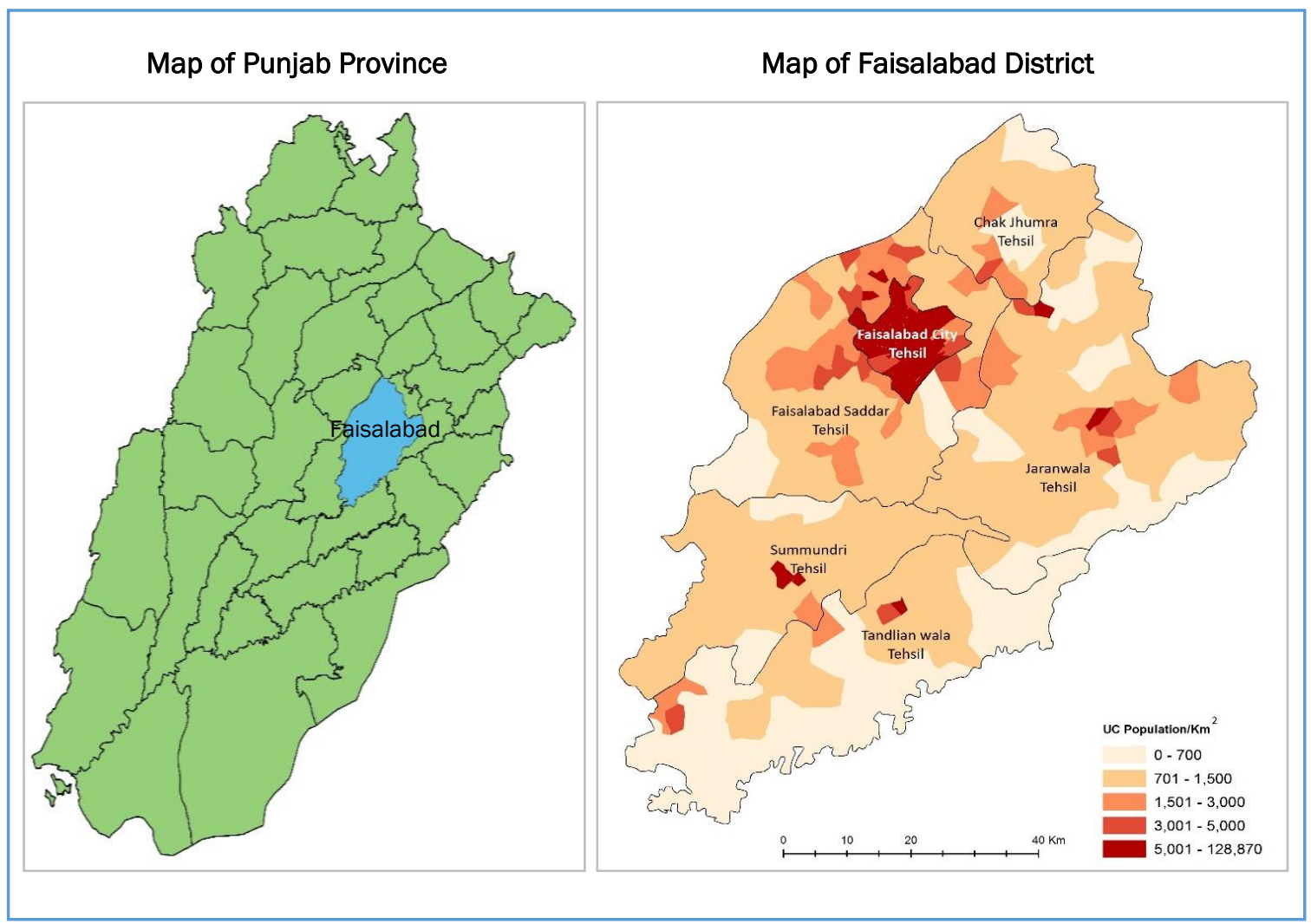

\section{Use of Antenatal and Delivery Care Services}

The majority of women in Faisalabad sought antenatal care from a skilled provider during their last pregnancy, A higher percentage of urban than rural women sought antenatal care ( $81 \%$ and $70 \%$ respectively). ${ }^{4}$
In both urban and rural areas, private facilities are the most common places of delivery. In urban areas, 64 percent of women delivered in private health institutions compared to 12 percent in public facilities. In rural areas, 48 percent of women delivered in private facilities, compared to 5 percent who delivered in public facilities.

\footnotetext{
${ }^{1}$ Punjab Development Statistics 2015

21998 Housing and Population Census

${ }^{3}$ Punjab Multiple Cluster Indicator Survey (MICS) 2014

${ }^{4}$ Pakistan Social and Living Standards Measurement Survey (PSLMS) 2014-15
} 


\section{Use of Family Planning}

The contraceptive prevalence rate (CPR) in Faisalabad is 37.6 percent, with prevalence of modern methods at 30.7 percent and traditional methods at 6.9 percent (Table 2). Contraceptive prevalence is higher in urban than rural areas (46.0\% and $29.4 \%$ respectively). Interestingly, use of traditional methods is much higher in urban areas of the district (10.9\%) compared to rural areas (3.0\%). Overall, unmet need is 17.6 percent, and is somewhat higher in rural areas (19.7\%) than in urban areas (15.4\%). The CPR in Faisalabad dropped from 41 percent in 2011, mostly due to changes in contraceptive use in urban areas; unmet need rose from 14.9 percent. ${ }^{5}$

Table 2: Contraceptive use and unmet need

\begin{tabular}{|c|c|c|c|c|c|}
\hline \multirow{2}{*}{\multicolumn{2}{|c|}{ District }} & \multicolumn{3}{|c|}{ Contraceptive Prevalence Rate (CPR) } & \multirow[b]{2}{*}{$\begin{array}{c}\text { Unmet } \\
\text { need }\end{array}$} \\
\hline & & Any Method & $\begin{array}{l}\text { Traditional } \\
\text { Methods }\end{array}$ & $\begin{array}{l}\text { Modern } \\
\text { Methods }\end{array}$ & \\
\hline \multirow[t]{3}{*}{ Faisalabao } & & 37.6 & 6.9 & 30.7 & 17.6 \\
\hline & Urban & 46.0 & 10.9 & 35.0 & 15.4 \\
\hline & Rural & 29.4 & 3.0 & 26.4 & 19.7 \\
\hline
\end{tabular}

Source: Punjab Multiple Cluster Indicator Survey (MICS) 2014

Figure 2 shows trends in use of contraceptive methods from 2011 to 2014 . Female sterilization and condoms are the most used methods, with use of each (particularly condoms) growing. Withdrawal is also used, particularly in urban areas, but prevalence of that method, among others, dropped from 2011 to 2014.

\section{Other Socio-economic Indicators}

The literacy rate (10 years and above) in Faisalabad is 69 percent. However, the rural literacy rate $(61 \%)$ is much lower than the urban literacy rate $(77 \%)$.

Three-quarters of households own a television set, but urban-rural differences are quite high, with 87 percent of urban households having a TV set compared to 66 percent of rural households. Mobile or landline phones are owned by the vast majority of households (95\%).

In terms of building materials, the main material used for roofs is garder (iron slabs)/T-Iron, which is used by 56 percent of houses in urban area and 80 percent in rural areas and other material used are RCC (reinforcement of concrete and cement), RBC (reinforcement of brick and cement), wood and bamboos. Virtually all houses (98\%) are constructed of burnt bricks or blocks in both urban and rural areas that indicates middle economic status.
Figure 2: Trend in contraceptive use among currently married women by method in Faisalabad

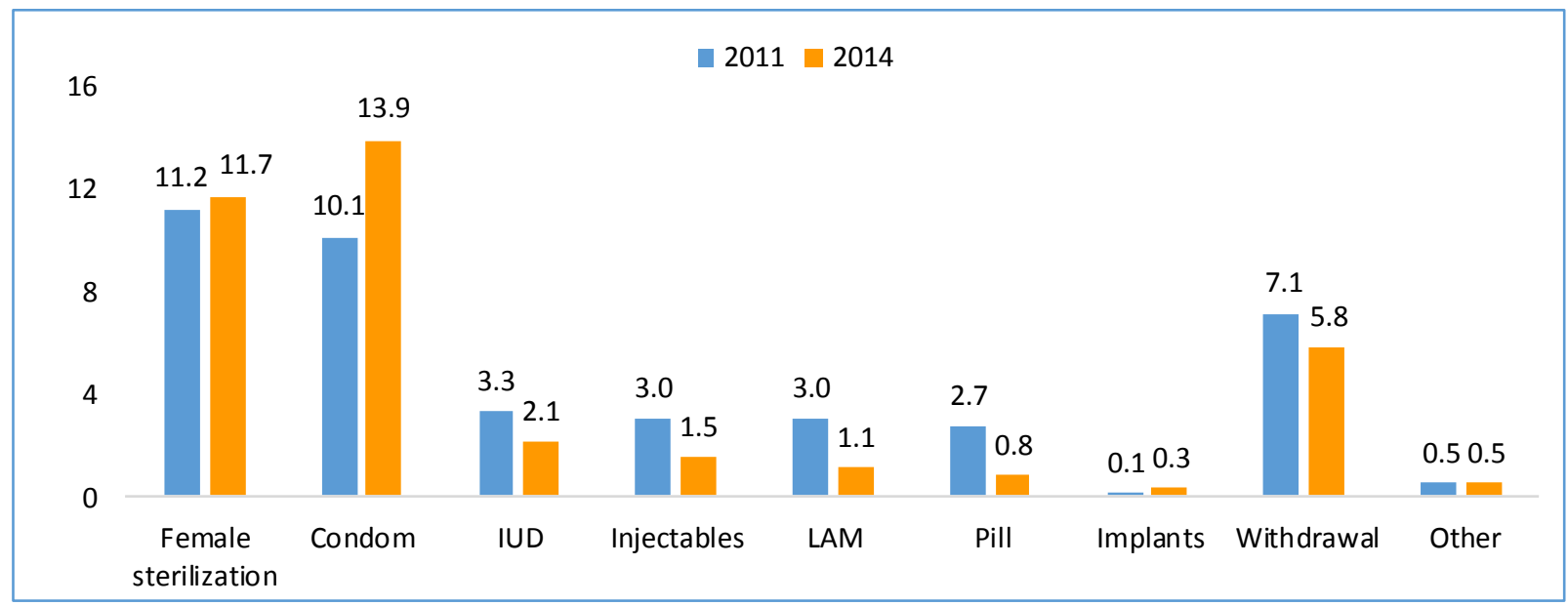

Source: - Punjab Multiple Cluster Indicator Survey (MICS) 2011 \& 2014

5 Punjab Multiple Cluster Indicator Survey (MICS) 2011 \& 2014 


\section{Avallability of Health Facilities, Pharmacies and LHWs}

During the landscape analysis of family planning, a census of public and private health facilities and pharmacies was carried out in the district. Figure 3 shows the breakdown of public and private health facilities and pharmacies in urban and rural areas of the district. Overall, private facilities are almost equally distributed across urban and rural areas (with private facilities having a larger share in urban areas), while pharmacies are more likely to be located in urban area (pharmacies comprise $37 \%$ of the health facility market in urban areas, compared to $13 \%$ in urban areas). Lady Health Workers (LHWs) comprise $41 \%$ of the share in rural areas, compared to $6 \%$ in urban areas. In comparison, presence of facilities of the Department of Health (DoH) and Population Welfare Department (PWD) is quite low.

Figure 3: Urban-rural distribution of health facilities and pharmacies in Faisalabad by sector, 2016
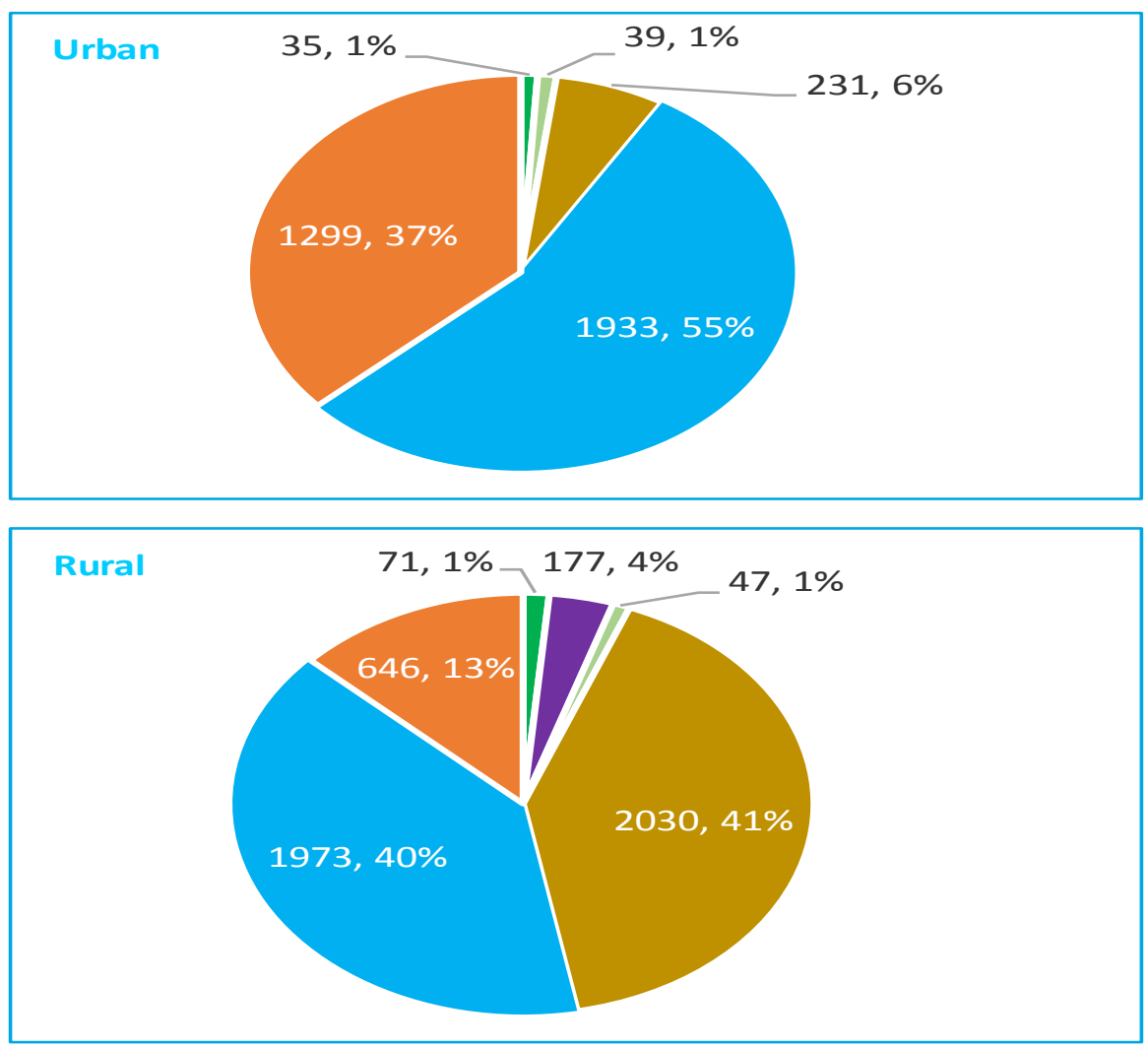

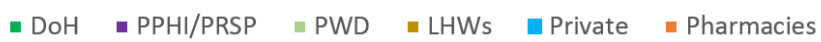

\section{Distribution of Public Static Facilities By Cadre}

Figure 4 shows the distribution of static public health facilities in urban and rural areas of Faisalabad. In urban areas, half (49\%) of the public facilities are Population Welfare Department (PWD) Family Welfare Centers (FWCs), followed by public hospitals (23\%) and dispensaries (21\%). In rural areas, People's Primary Health Initiative/Punjab Rural Support Program (PPHI/PRSP) facilities comprise the largest share (60\%), followed by dispensaries (18\%) and FWCs (15\%). In both urban and rural areas, Maternal Child Health $(\mathrm{MCH}) /$ Maternity Centers of DoH and PWD's Reproductive Health Service Centers (RHS-A) and Family Health Centers (FHC) comprise relatively small shares.

Figure 4: Cadre-wise Urban-rural distribution of static public facilities in Faisalabad, 2016
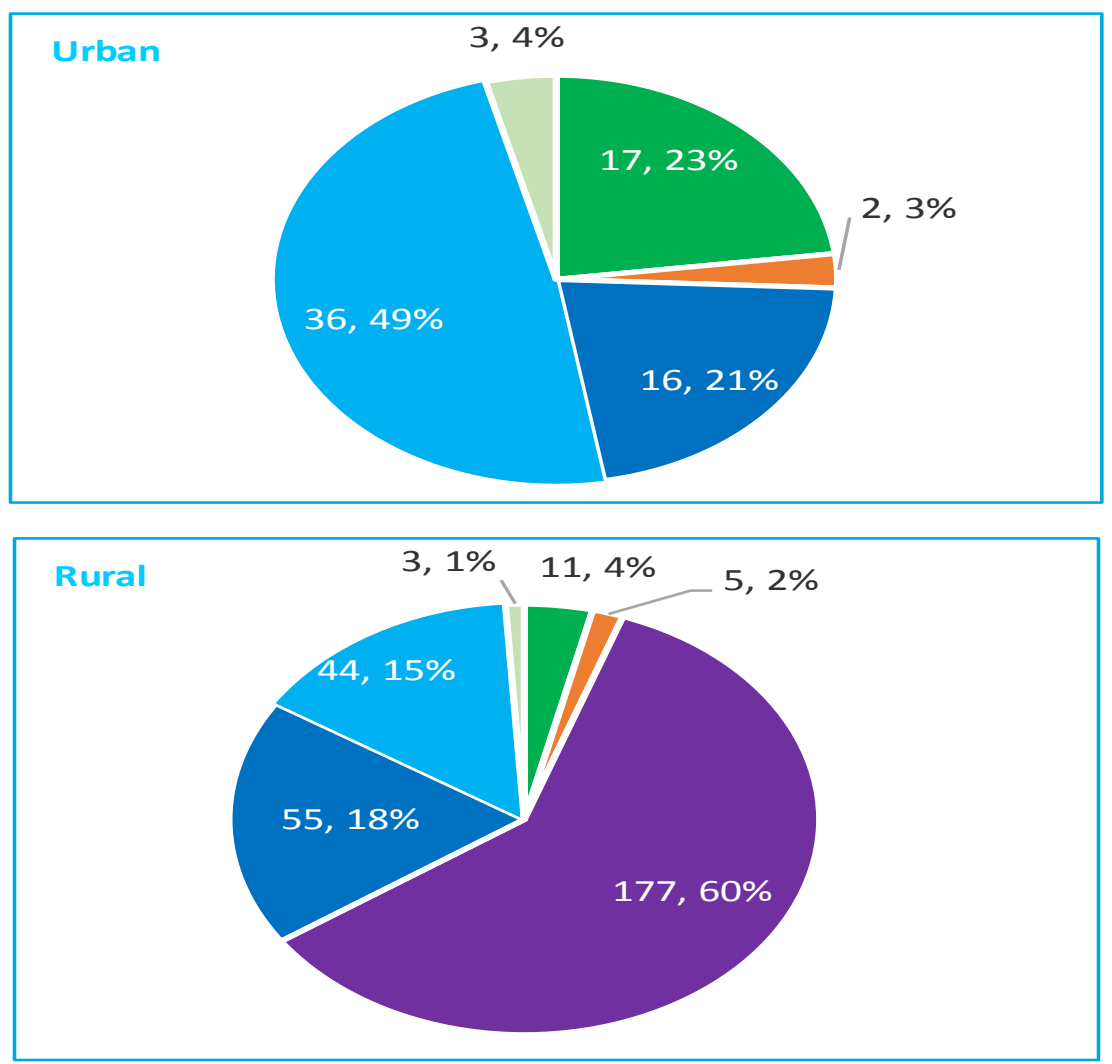

- Public Hospitals $=\mathrm{MCH} /$ Maternity Centers - PPHI/PRSP - Dispensaries $\square$ FWCs $\backsim$ RHSC-A/FHCs 


\section{Distribution of Private Facilities by Cadre}

Figure 5 shows distribution of private facilities in urban and rural areas of Faisalabad. In urban areas, homeopath/hakeem clinics are largest in number $(55 \%)$ followed by dispenser clinics (13\%), private hospitals $(12 \%)$ and male doctor clinics $(11 \%)$. In rural areas dispenser clinics are largest in number (51\%), followed by homeopath/hakeem clinics (33\%), and midwife/nurse/Lady Health Visitor (LHV) clinics (8\%). Clinics of female providers comprise 3 percent of providers in urban areas and less than 1 percent in rural areas. Likewise, presence of NGO facilities is very small.

Figure 5: Cadre wise urban-rural distribution of private facilities in Faisalabad, 2016

\section{Provision of Specific Family Planning Methods by \\ Sector}

Table 3 shows proportion of different sectors providing specific family planning methods in urban and rural areas. Overall, availability of methods tends to be better in urban areas types of providers. DoH facilities are providing most methods, particularly in rural areas. PWD facilities are providing most methods both in urban and rural areas. LHWs are providing condoms, pills and $2^{\text {nd }}$ doses of injectable. Only a fraction of private facilities, while large in numbers, provide any

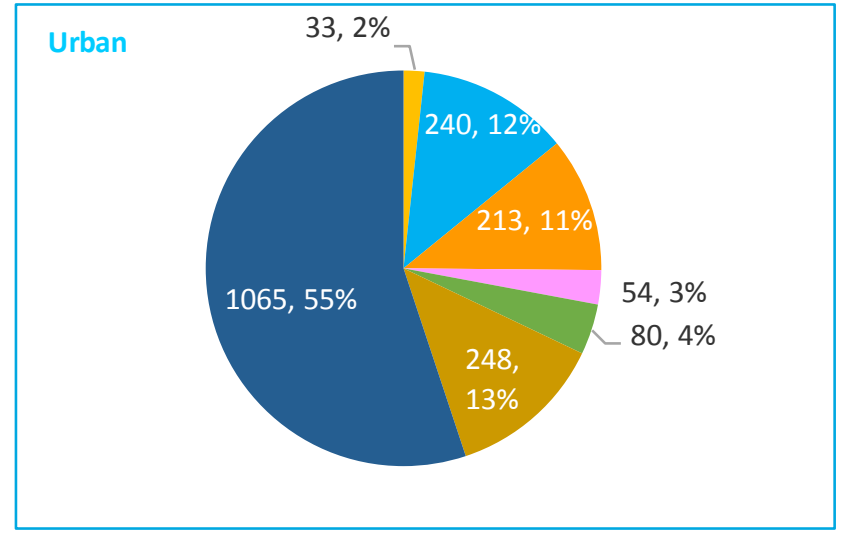

= NGO Clinics

- LHV/Nurse/Midwife Clinics - Dispenser Clinics

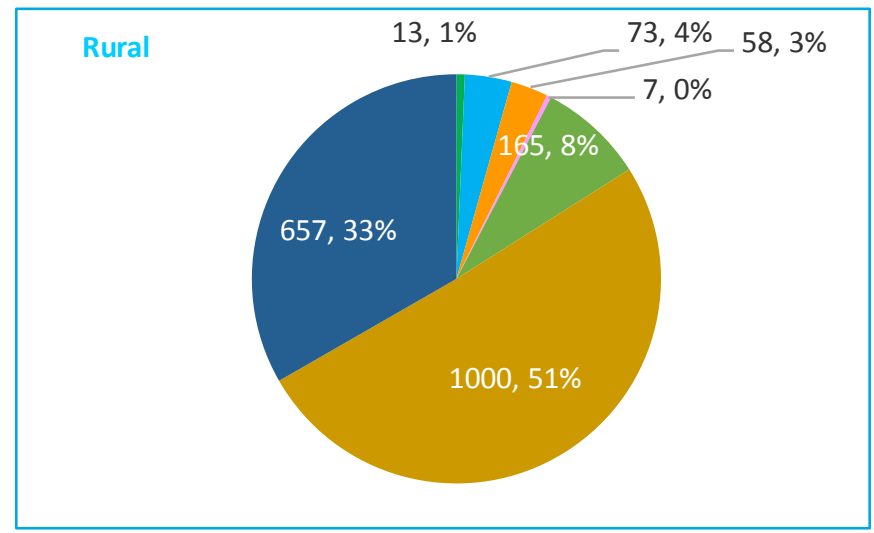

- Male Doctor Clinics

- Homeopath/Hakeem Clinics methods. Pharmacies particularly offer condoms, oral pills and ECP, particularly in urban areas. There is huge potential for increased provision of methods in all sectors. For example, LHWs could provide the $1^{\text {st }}$ dose of injectables and also ECPs. Implants and male sterilization are hardly provided and female sterilization is provided only by 20 percent of $\mathrm{DoH}$ facilities in urban areas and in a small percentage of private facilities and PWD facilities in urban areas.

Table 3: Provision of specific family planning methods in Faisalabad by sector, \%, 2016

\begin{tabular}{|c|c|c|c|c|c|c|c|c|c|c|c|c|c|c|c|c|c|c|}
\hline \multirow[t]{2}{*}{ Sector } & \multicolumn{2}{|c|}{ Condoms } & \multicolumn{2}{|c|}{ OCPs } & \multicolumn{2}{|c|}{ Injectables } & \multicolumn{2}{|c|}{ IUDs } & \multicolumn{2}{|c|}{ ECPs } & \multicolumn{2}{|c|}{ Implants } & \multicolumn{2}{|c|}{$\begin{array}{c}\text { Female } \\
\text { Sterilization }\end{array}$} & \multicolumn{2}{|c|}{$\begin{array}{c}\text { Male } \\
\text { Sterilization }\end{array}$} & \multicolumn{2}{|c|}{$\begin{array}{l}\text { Number of } \\
\text { Facilities/ } \\
\text { Pharmacies }\end{array}$} \\
\hline & $\mathrm{U}$ & $\mathrm{R}$ & U & $R$ & U & $R$ & U & $R$ & $\mathrm{U}$ & $\mathrm{R}$ & $\mathrm{U}$ & $\mathrm{R}$ & $\mathrm{U}$ & $\mathrm{R}$ & $\mathrm{U}$ & $\mathrm{R}$ & U & $R$ \\
\hline $\mathrm{DoH}$ & 51 & 54 & 63 & 54 & 63 & 49 & 66 & 42 & 29 & 7 & 9 & 0 & 20 & 0 & 6 & 0 & 35 & 71 \\
\hline PPHI/PRSP & - & 86 & - & 92 & - & 86 & - & 80 & - & 18 & - & 3 & 0 & 0 & 0 & 0 & 0 & 177 \\
\hline PWD & 41 & 38 & 49 & 45 & 49 & 43 & 46 & 34 & 28 & 32 & 3 & 2 & 3 & 0 & 3 & 0 & 39 & 47 \\
\hline LHWs & 100 & 100 & 100 & 100 & 100 & 100 & NA & NA & NA & NA & NA & NA & NA & NA & NA & NA & 290 & 1956 \\
\hline Private & 2 & 5 & 8 & 9 & 8 & 7 & 8 & 3 & 1 & - & 1 & - & 1 & 4 & 3 & 1 & 1933 & 1973 \\
\hline Pharmacies & 62 & 41 & 46 & 25 & 22 & 10 & 0 & 0 & 42 & 18 & 0 & 0 & NA & NA & NA & NA & 1299 & 646 \\
\hline
\end{tabular}

NA: Not applicable, U: Urban, R: Rural, ECP: emergency contraceptive pill, IUD: intrauterine device, OCP: oral contraceptive pill 


\section{Presence and Provision of Family Planning Services/Products: A Comparison}

Figure 6 presents pairs of maps showing the presence of public health facilities, private health facilities, and pharmacies, respectively, and actual provision of family planning services/products by each category of facility. Figure 6 shows that 90 percent of static public health facilities and 13 percent of private sector facilities are providing family planning, Two-thirds $(66 \%)$ of pharmacies are selling family planning products.

Figure 6: Proportion of static public health facilities providing at least one FP service, 2016
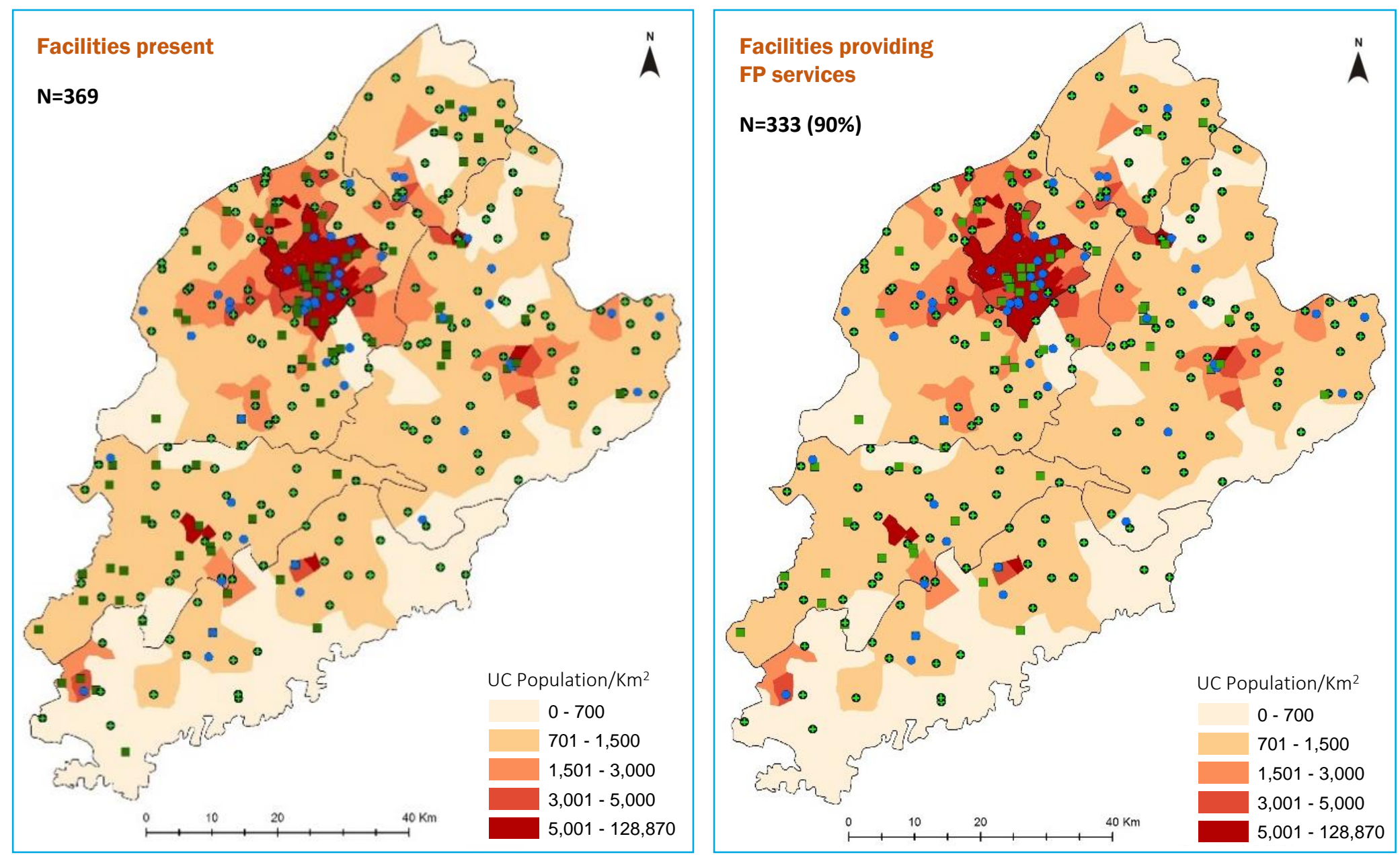

- Department of Health $(\mathrm{DoH})$

- Punjab Rural Support Programme (PRSP)

- Population Welfare Department (PWD) 
Figure 7: Proportion of Private health facilities providing at least one FP service, 2016

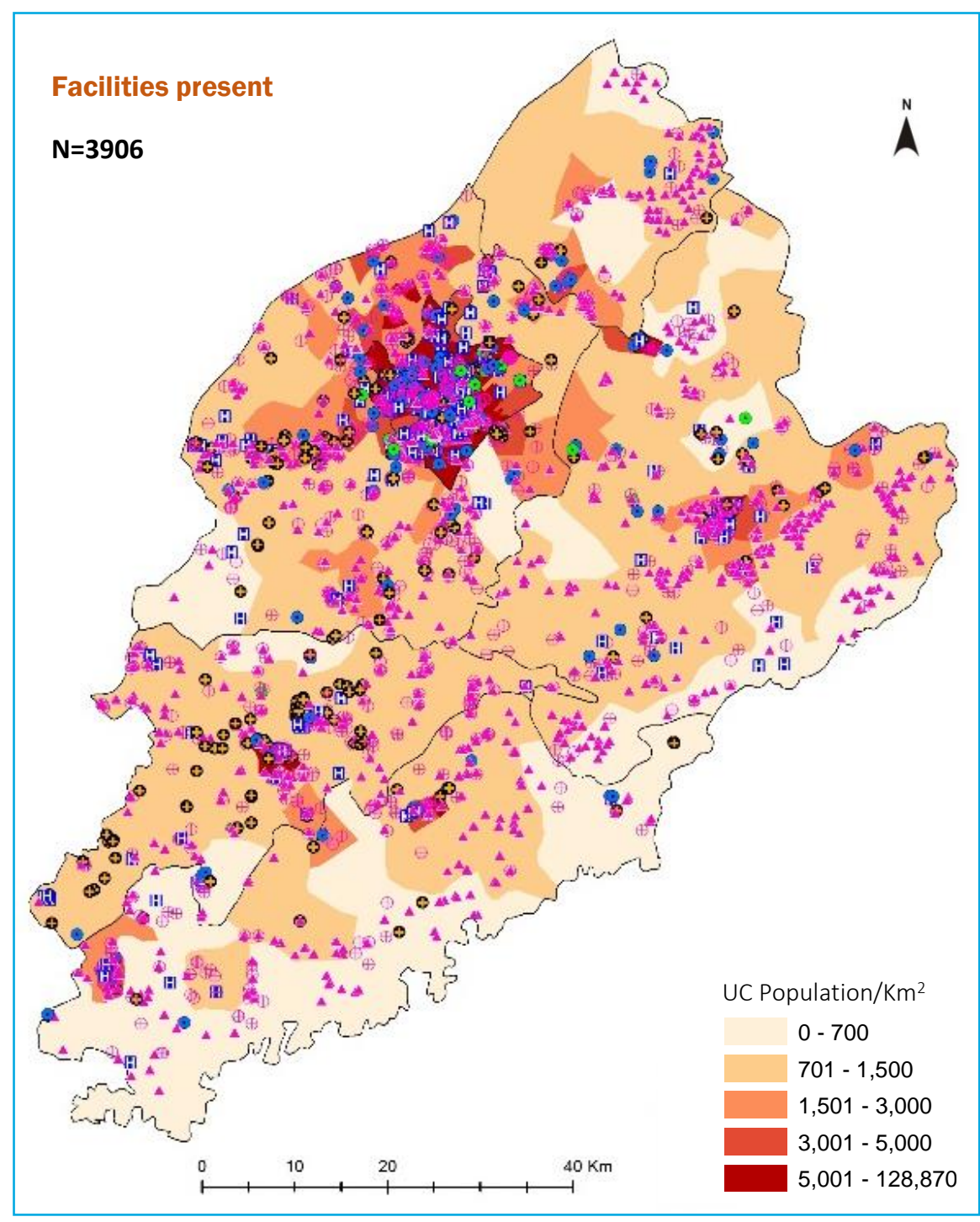

(1) Private Hospitals

- Male Doctor Clinics

- Female Doctor Clinics

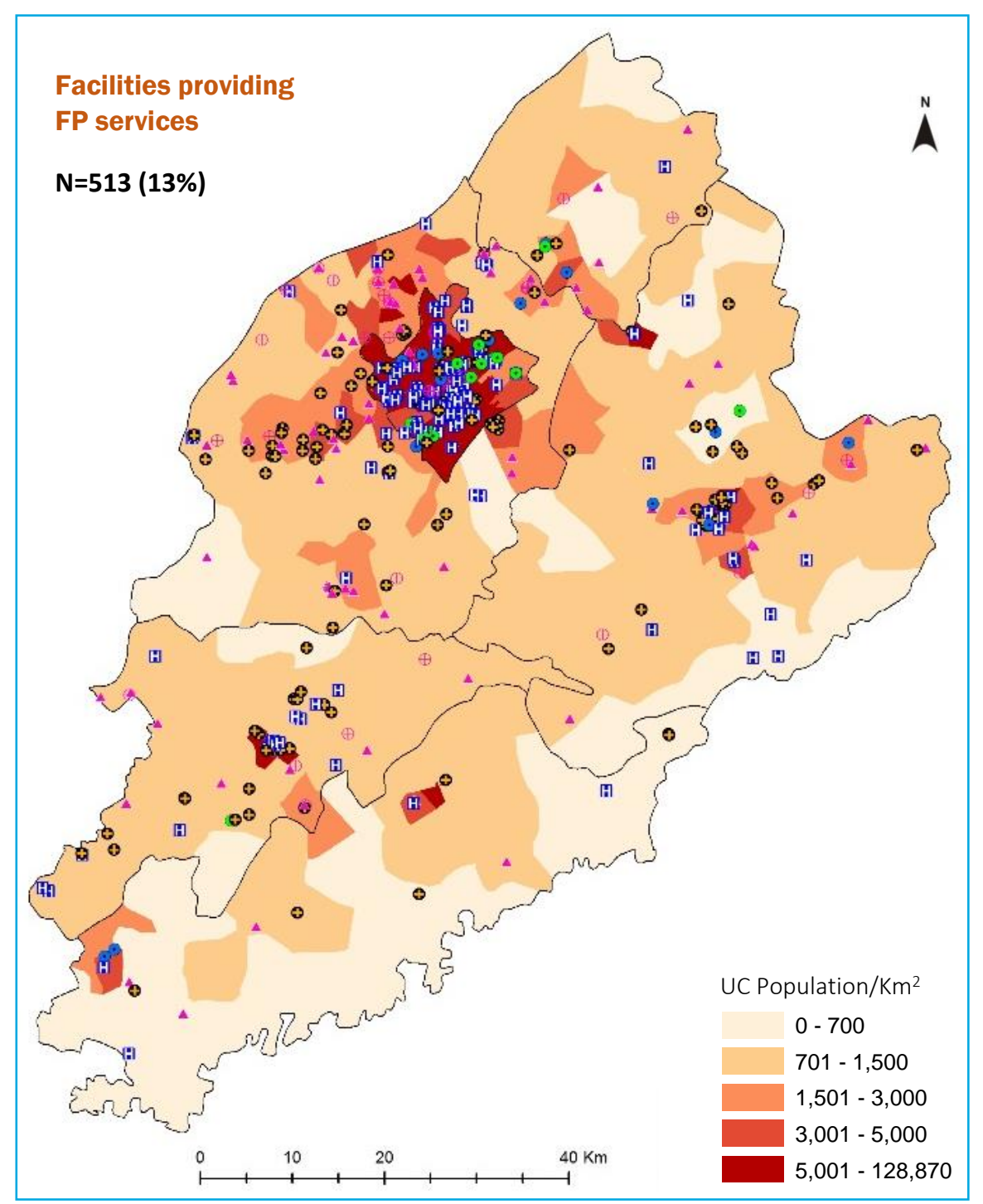

- LHV/Nurse/Midwife Clinics

4. Dispenser Clinics

$\oplus \quad$ Homeopath/Hakeem Clinics 

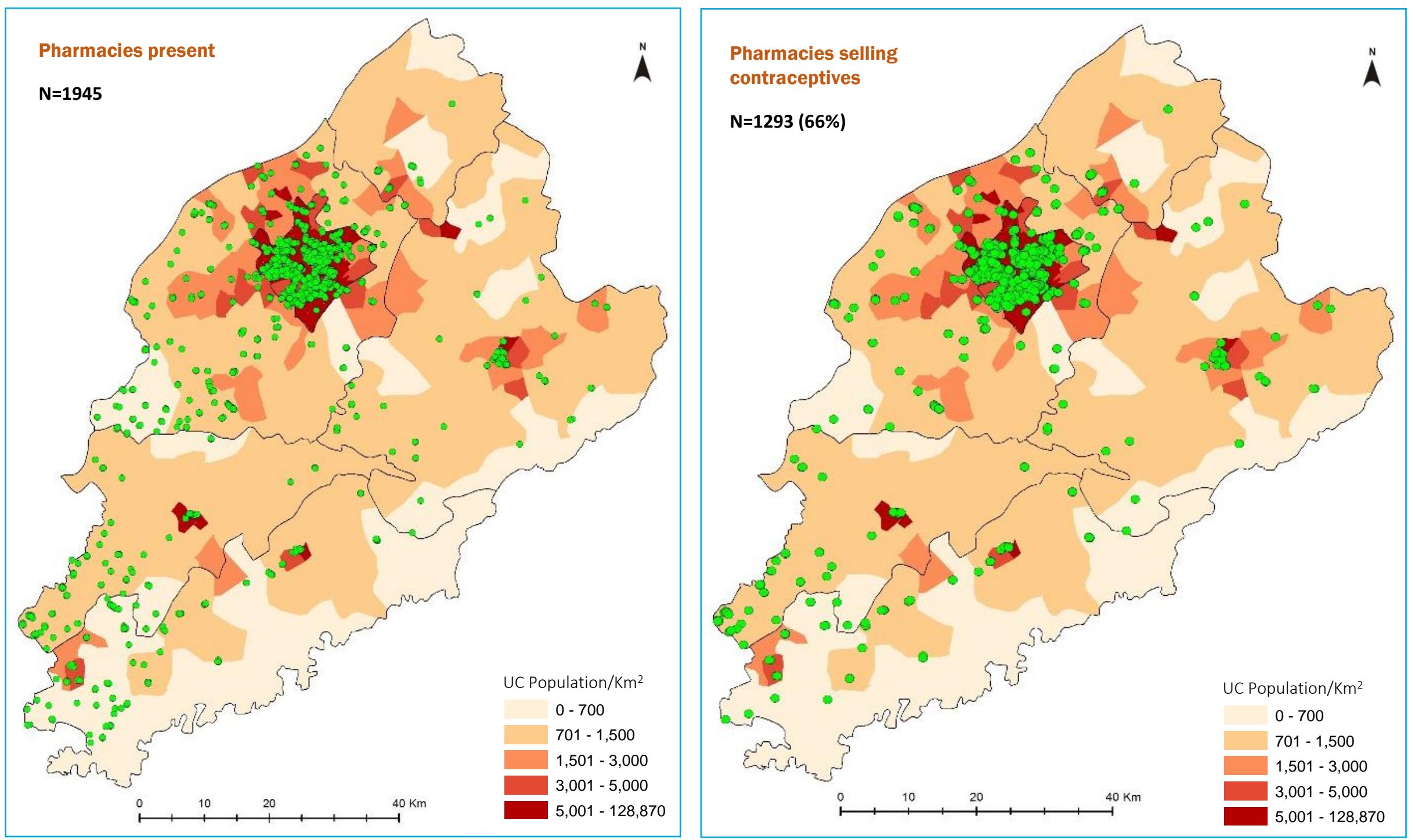


\section{Consumers' Perspectives on Barriers to use of Family Planning}

During the landscape assessment, the study team collected the views of 126 men and women on family planning through 47 in-depth discussions and eight focus group discussions (FGDs) held in Faisalabad. In Faisalabad Tehsil, Madina Town and Jinnah Town were included to represent city respondents' perspective. Tehsil Jaranwala was chosen for a rural perspective and parts of Tehsil Sumandri covered a town perspective.

Three common strong barriers to use of family planning were identified both from rural and urban areas, including lack of information on family planning especially for men; poor quality of FP services at public facilities; and cost of services, among poor couples. Problems in accessing services is an issue for the rural communities.

Lack of information for men in both rural and urban men is a major barrier for family planning adoption. Men want more information. Men are reluctant to discuss family planning with other men both in rural and urban areas.

- Since men do not have any direct source of FP information, they rely information provided by their friends, which is not necessarily to be correct

"Yes, there should be knowledge about family planning and only then we can use these methods. Otherwise we won't be able to do that. The major issue is that we don't have information about family planning." Male, Faisalabad city

- In both urban and rural areas, men do not discuss family planning in groups or in gatherings since they considering it a personal matter. If they do talk about it, they do so in a joking manner.

"People usually share in a sense of fun; thus they can talk about this [family planning]. I never had a chance to discuss about this in social events." Male, Faisalabad city

- In urban areas, men feel embarrassment to purchase condoms in markets, due to stigma associated with use of condoms

"There is no problem, condoms are easily available. We just feel a bit of hesitation asking for condoms so I whisper to the store keeper and then he provides. Or I point towards the method." Male, Faisalabad, city

"We are a bit shy and feel hesitation to get this method from the market." Female, Faisalabad city

For urban areas, poor quality of services at public facilities discourages women from seeing services.

Since women from rural areas are mainly dependent on LHWs for their methods, they have less interaction with static health facilities unless they want to get an IUD, Implant or a sterilization.

- In urban areas, use of IUD is quite common, thus women seek services from public facilities where they face multiple problems of quality such as: a) over-crowed facilities; b) lack of attention and mistreatment by service providers; c) lack of privacy; d) lack of information and counseling; e) poor technical competence of providers; $f$ ) medicines prescribed from the market.

"All government hospitals have the same conditions. Staff don't behave well, they insult us when we go there, and they scold us, and they do not listen to us. There is always a big que at the slip counter. They don't care even if a woman delivers the baby in the corridor. This is why people prefer the private hospitals and clinics." Female, Faisalabad city

"They do not provide privacy and treat the women outside in the corridor. They ask us to take our clothes off in front of other female patients. The majority of people go to private facilities because of these conditions." Female, Faisalabad city

"People don't have much knowledge about birth spacing and family planning because the people are getting ignored in the government hospitals and no information is provided. But most people are very poor so they cannot afford treatment from private facilities." Male, Faisalabad city 
In rural areas, the cost of contraceptives and travel costs are barriers for poor couples who are using family planning methods

- If there is no public facility available in the area, they cannot manage the expenses of traveling to get family planning.

"If the facility will be near then I am sure that women will not mind spending 10-20 rupees. But they won't go far."

Female, Faisalabad city
- In rural areas people are getting condoms, pills and the injections beyond the $1^{\text {st }}$ injection from the LHW at their door step, thus there is no price barrier. However, when LHWs experience stock outs, then users have to buy from urban areas, which is an untenable expense for many.

"Our government does not provide methods to LHWs. So what will LHWs give to women? It costs 100 Rupees to get the contraceptive injection from the pharmacy. Round trip fare to Jaranwala (city) is 200 Rupees and if you add wages for that day of 300 Rupees, then this contraceptive injection would cost us 600 rupees." Male, Faisalabad rural 


\section{District specific Donors, Projects and Implementing partners}

\begin{tabular}{|c|c|c|}
\hline Donor & Program/ Project Title & Implementing Partner \\
\hline DFID & $\begin{array}{l}\text { Delivering Reproductive Health Results (DRHR) } \\
(2012-2017)\end{array}$ & $\begin{array}{l}\text { Population Services International (PSI)/ Greenstar Social } \\
\text { Marketing (GSM) } \\
\text { Marie Stopes International: Reproductive Health Franchise } \\
\text { DKT International/Pakistan }\end{array}$ \\
\hline \multirow[t]{2}{*}{$\begin{array}{l}\text { Bill and Melinda Gates } \\
\text { Foundation }\end{array}$} & $\begin{array}{l}\text { Building Blocks for Family Planning in Pakistan - Developing a Costed } \\
\text { Implementation Plan for Sindh and Punjab. (2013-2015) }\end{array}$ & Pathfinder International \\
\hline & Landscape Analysis of the Family Planning Situation in Pakistan. (2015-2016) & Population Council \\
\hline \multirow[t]{4}{*}{$\begin{array}{l}\text { The David \& Lucile } \\
\text { Packard Foundation }\end{array}$} & $\begin{array}{l}\text { Demand-Side Financing for Increasing Demand and Utilization of Contraception for } \\
\text { Birth Spacing in Punjab Province, Pakistan. (2011-2015) }\end{array}$ & $\begin{array}{l}\text { Population Services International } \\
\text { Greenstar Social Marketing }\end{array}$ \\
\hline & $\begin{array}{l}\text { Comparative Impact Evaluation: Demand Side Financing for Increasing Demand and } \\
\text { Utilization of Birth Spacing in Punjab Province, Pakistan. (2011-2015) }\end{array}$ & World Health Organization (WHO) \\
\hline & $\begin{array}{l}\text { Achieving MDG5 - Continuing Momentum, Building Champions } \\
\text { 2012-2015 }\end{array}$ & Shirkat Gah Women Resource Centre \\
\hline & Strengthening and Sustaining Postpartum Family Planning in Pakistan. 2013-2015 & JHU - JHPIEGO \\
\hline USAID & $\begin{array}{l}\text { Deliver Project } \\
(2008-2016)\end{array}$ & $\begin{array}{l}\text { The Planning Commission of Pakistan, The Ministry of Health } \\
\text { (MOH), Provincial and Regional Departments of Health and } \\
\text { Population, UNFPA, and NGOs }\end{array}$ \\
\hline \multirow[t]{2}{*}{ UNFPA } & $\begin{array}{l}\text { Capacity Building of Female Service Providers Enhanced in Family Planning. } \\
\text { 2014-2017 }\end{array}$ & $\begin{array}{l}\text { Population Welfare Departments } \\
\text { MNCH Programs } \\
\text { LHWs Program }\end{array}$ \\
\hline & $\begin{array}{l}\text { Advocacy for Universal Access to Reproductive Health and to Integrate in Provincial } \\
\text { Health Policies, Plans and Budgetary Frameworks. } \\
(2012-2017)\end{array}$ & $\begin{array}{l}\text { Population Welfare Departments } \\
\text { Population Council } \\
\text { Pathfinder International } \\
\text { Ministry of National Health Services, Regulations and } \\
\text { Coordination }\end{array}$ \\
\hline $\begin{array}{l}\text { World Health Organization } \\
\text { (WHO) }\end{array}$ & $\begin{array}{l}\text { Providing Technical Assistance to Develop a Unified Care Providers Manual on FP } \\
\text { Based on the WHO Handbook on FP. }\end{array}$ & $\begin{array}{l}\text { Ministry of National Health Services Coordination and Regulation } \\
\text { MNCH programs } \\
\text { UNFPA, Population Council, GIZ, USAID }\end{array}$ \\
\hline $\begin{array}{l}\text { Large Anonymous Donor } \\
\text { (LAD) }\end{array}$ & $\begin{array}{l}\text { Increasing Access to and use of Long Term Methods of FP and PAC Services in } \\
\text { Pakistan (2014-16) }\end{array}$ & Greenstar Social Marketing \\
\hline
\end{tabular}

